\title{
Thermo-Hygrometric Variability on Waterfronts in Negative Radiation Balance: A Case Study of Balneário Camboriú/SC, Brazil
}

\author{
Cássio Arthur Wollmann ${ }^{1, *(\mathbb{D}}$, Ismael Luiz Hoppe ${ }^{1}{ }^{1}$, João Paulo Assis Gobo ${ }^{2}{ }^{\mathbb{D}}$, \\ João Paulo Delapasse Simioni ${ }^{3} \mathbb{D}$, Iago Turba Costa ${ }^{1} \mathbb{D}$, Jakeline Baratto ${ }^{1} \mathbb{D}$ and Salman Shooshtarian ${ }^{4}(\mathbb{D}$ \\ 1 Department of Geosciences, Natural and Exact Sciences Center, Federal University of Santa Maria, \\ Santa Maria 97105-900, Brazil; ismael.hoppe@hotmail.com (I.L.H.); iagoturba06@gmail.com (I.T.C.); \\ jekeline.jake@hotmail.com (J.B.) \\ 2 Department of Geography, Core of Exact Earth Sciences, Federal University of Rondônia, \\ Porto Velho 76801-059, Brazil; joao.gobo@unir.br \\ 3 Department of Geography, Institute of Geosciences, Federal University of Rio Grande do Sul-Brazil, \\ Porto Alegre 90040-060, Brazil; geojoaopaulo@gmail.com \\ 4 School of Property, Construction and Projetc Management Royal Melbourne Institute of Technology, \\ Melbourne, VIC 3001, Australia; salman.shooshtarian@rmit.edu.au \\ * Correspondence: cassio@ufsm.br
}

check for updates

Citation: Wollmann, C.A.; Hoppe, I.L.; Gobo, J.P.A.; Simioni, J.P.D.; Costa, I.T.; Baratto, J.; Shooshtarian, S. Thermo-Hygrometric Variability on Waterfronts in Negative Radiation Balance: A Case Study of Balneário Camboriú/SC, Brazil. Atmosphere 2021, 12, 1453. https://doi.org/ 10.3390/atmos12111453

Academic Editor: Anthony R. Lupo

Received: 25 September 2021

Accepted: 30 October 2021

Published: 3 November 2021

Publisher's Note: MDPI stays neutral with regard to jurisdictional claims in published maps and institutional affiliations.

Copyright: (c) 2021 by the authors. Licensee MDPI, Basel, Switzerland. This article is an open access article distributed under the terms and conditions of the Creative Commons Attribution (CC BY) license (https:/ / creativecommons.org/licenses/by/ $4.0 /)$.
Abstract: Extensive urbanization around the world has resulted in the consumption of massive vegetated areas and natural resources. To this end, one strategy for urban development is to consolidate urban areas. In Balneário Camboriú/SC, Brazil, this trend has transformed the city into a vertical built-up area on its coastal strip, accommodating a large amount of buildings both in terms of quantity and number of floors. This research aims to quantify the thermo-hygrometric fluctuation on the waterfront of Balneário Camboriú, in negative radiation balance. To acquire the data on air temperature (Ta) and relative humidity $(\mathrm{RH})$, two mobile transects and measuring at two fixed points were made in a situation of negative radiation balance on 26 August 2019, in the winter period of the Southern Hemisphere. The collection work began at 06:00:00 a.m. (before sunrise, the peak of the negative radiation balance), on Atlântica Avenue (waterfront) and Brasil Avenue (parallel to the waterfront). It was verified that the Ta varied from $16.0^{\circ} \mathrm{C}$ to $19.0^{\circ} \mathrm{C}$, and the $\mathrm{RH}$ remained over $80 \%$ during the entire route. At the meteorological shelters, the temperature presented a variation from $14.4{ }^{\circ} \mathrm{C}$ to $17.7^{\circ} \mathrm{C}$, and the $\mathrm{RH}$ ranged from $79.6 \%$ to $91.3 \%$ between the two points. The spatial variability in the Ta and $\mathrm{RH}$ along the paths travelled and at the fixed points is directly related to the land cover, represented especially by the buildings' verticalization and data collection time.

Keywords: Balneário Camboriú; land cover; waterfront; air temperature; relative humidity; negative radiation balance

\section{Introduction}

Urban areas produce their own microclimate and result from the interference of all the urban elements that alter the climate at the local scale [1]. For instance, [2] states that insofar as cities expand their built-up areas and increase their vertical density, the impacts on the air, soil, water, and life, both within and around them, also amplify the environmental problems that affect the wellbeing of urban society [3-5].

According to [6-8], densely verticalized urban areas are represented by a wide variety of canyons, as well as a variety in the proportion between street width and building size and height. For example, due to buildings being different shapes and sizes, they form different urban canyons and shading, which reduces the amount of longwave solar radiation that reaches the surface during the day [9-14]. Ta at the urban canopy decreases according to the type of construction, in particular building verticality; in other words, the taller the buildings are, the greater this thermal decrease at the urban canopy will be [15-17]. 
Ground shading occurs in the verticalized areas with the presence of urban canyons, and these areas reduce the amount of energy stored during the day, which implies a less significant emission of long waves by the canopy surfaces at night [18-21].

Therefore, many works discuss the role of urban canyons, or large canyons of buildings, in the variability in air temperature and relative humidity, as they modify the amount of solar radiation and the times at which it reaches the surface [22-25]. In this context, it can still be highlighted that, precisely because of the existence of this urban geometry [26,27], many areas have a delay in receiving solar energy after sunrise, remaining in a situation of negative radiation balance for longer [28-31].

As the maximum negative solar radiation balance is the starting point for studies of the beginning of the daily variation in climatic elements, some works have focused on quantification and the effects of urban geometry on air temperature and relative humidity during these periods of the day and in some seasons [32,33].

Among the research in this field, the research by [34] stands out, which deals with the impacts of urban surface on radiation balance and meteorological variability in Beijing. In this study, the authors quantified the relationship between solar radiation, urban geometry, and heat fluxes. In this same line of investigation, [35-37] carried out similar research.

Recently, other authors go further, discussing the radiation balance with the materials [38] that make up the city and its relationship with mesoscale climatic conditions [39-41] using remote sensing tools. However, some authors discuss the variability in the city's thermo-hygrometric field at specific times of the day, such as the maximum or minimum amount of solar radiation and its balance [42-46].

\section{Study Aim and Objectives}

Within this theoretical context, in which the origin of the variation in the solar radiation balance is an extra-urban component [18], the skyscrapers concentrated at the waterfront of Balneário Camboriú cause the shading of streets and the beach, promoting permanent negative balance situations for the city, in areas that will never receive direct solar radiation again, i.e., a positive radiation balance will no longer occur.

In this context, this article presents, as its general objective, the measuring and analysis of the spatial variability in the Ta and RH on the coastal strip of the urban area of Balneário Camboriú, Santa Catarina-SC, using two mobile transects and measuring at two fixed points, in a situation of negative radiation balance (before sunrise) in the winter.

This is the first approach in an urban environment with such characteristics in the Brazilian subtropical coastline, which has areas where there is an almost permanent negative radiation balance that may intensify when there are no long waves from the sun or just in the beginning of the morning.

This research is part of a large-scale project studying the urban climate of Balneário Camboriú, Brazil. In 2019, the team started the research by carrying out transects in the city, in order to assess whether this method would be the best or not (methodological tests). It was found that during the early morning hours, such transects could be performed, as there is almost no traffic on the city's avenues and main streets; however, from 9 a.m. and until late at night, there is a large amount of movement of cars, trucks and pedestrians in the city, movement caused both by residents and tourists, as well as construction workers and trucks.

Initially it was planned that, in early 2020, a network of weather shelters would be installed however, the entire world was surprised by the COVID-19 pandemic, and the research and installation of equipment stopped until July 2021. During the period of successive quarantines due to the COVID-19 pandemic, no collection was possible. At this time, there is network with 24 automatic weather stations installed in the city, and transects will be carried out again at different times of the day and during different seasons. 


\section{Materials and Methods}

\subsection{Case Study}

The study area of this research is the coastal strip (considering only the first block of buildings between the sand strip and the first avenue parallel to the waterfront) of the central area of the municipality of Balneário Camboriú, located in the Brazilian state of Santa Catarina (SC). The city is located on the state's northern coast, at a latitude of $26^{\circ} 59^{\prime} 42^{\prime \prime}$ South and longitude of $48^{\circ} 37^{\prime} 46^{\prime \prime}$ West. Balneário Camboriú borders three municipalities (Itajaí, Itapema, and Camboriú) and the Atlantic Ocean on the east. The primary access to the municipality is through federal highway BR-101 (Figure 1).

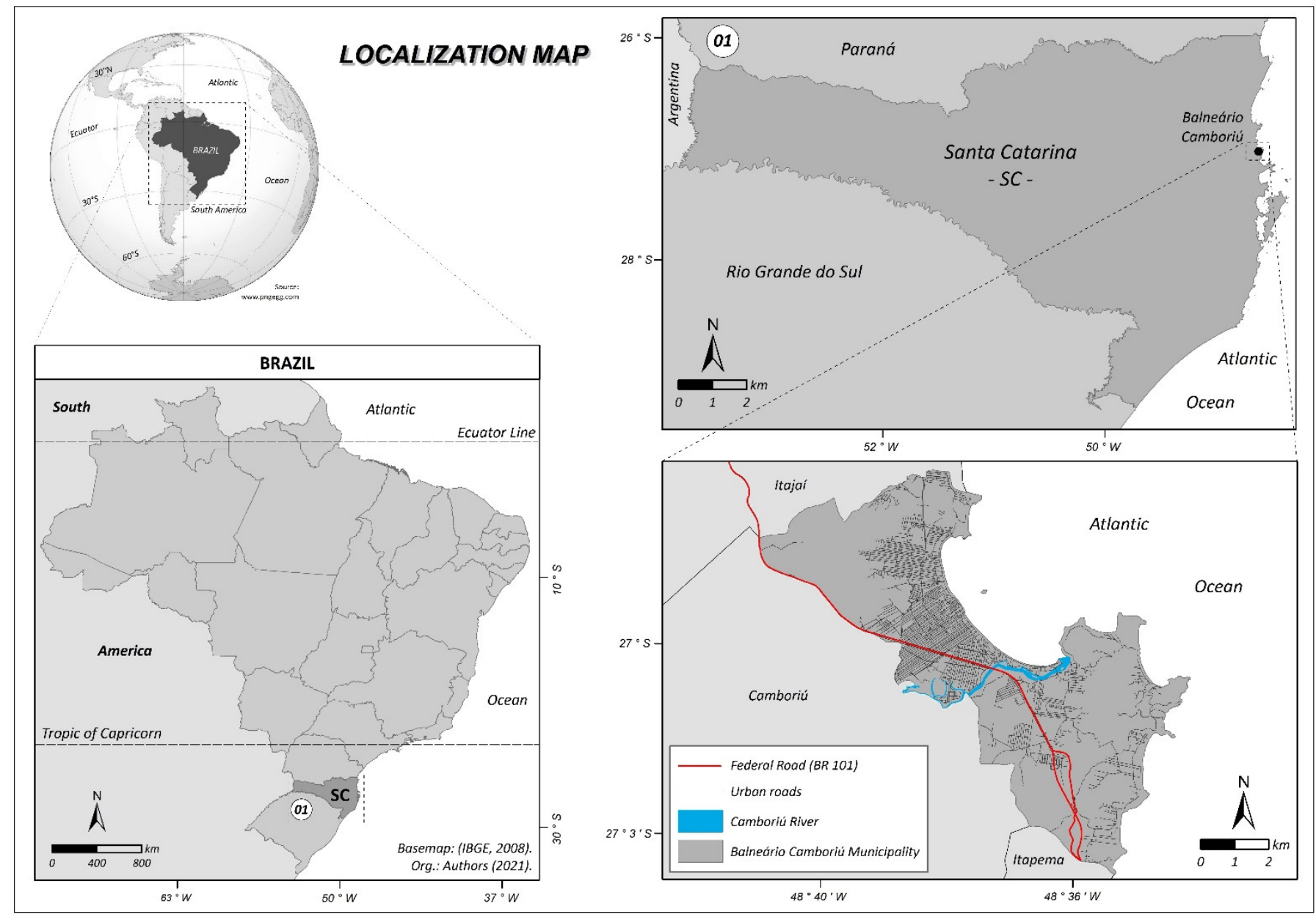

Figure 1. Localization map of Balneário Camboriú/SC, Brazil.

The verticalization process recorded in the study area is not recent; it dates back to the 1950s, when the then Brazilian president, Juscelino Kubitschek, chose the city as the location for his summer home, and the area became known as the "president's beach". However, in the 1960s the tourist activity boosted the city as a major Brazilian tourist center. Previously, in 1959, it was elevated to the District of Camboriú, but in 1964, the municipality of Balneário Camboriú was created; however, skyscrapers with over fifty floors are a novelty of the last decade [47].

The city has an estimated population of 146 thousand inhabitants, according to the Brazilian Institute of Geography and Statistics (IBGE). It is worthy of note that $100 \%$ of the inhabitants are domiciled in the urban areas because the municipality has no rural area. Of the population, $52.4 \%$ are female and $47.6 \%$ are male, and they are divided into fourteen neighbourhoods, with a population density of 2337.67 inhabitants per squared kilometer [48]. 
On a waterfront with an extension of less than $6 \mathrm{~km}$, located entirely in the Centro neighbourhood, and with a total urban area of only $46 \mathrm{~km}^{2}$ through which 90 thousand vehicles circulate, the most accentuated verticalization process in Brazil and also of the entire Southern Hemisphere is observed [49], the reason for which the municipality is deemed the "Brazilian Dubai", given that, of the ten highest buildings of the country, eight are in Balneário Camboriú (Figure 2).

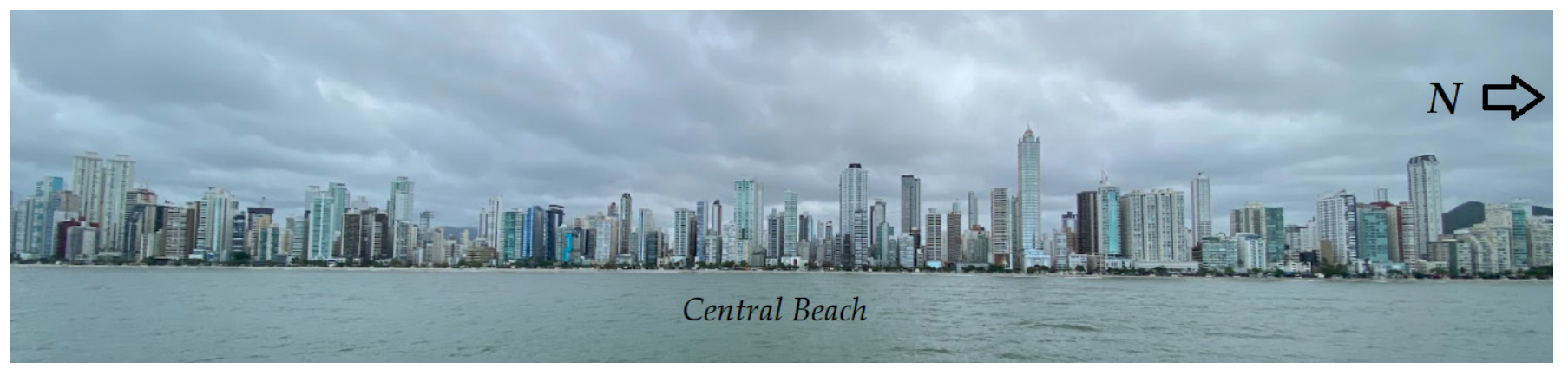

Figure 2. Panoramic view of the waterfront of Balneário Camboriú/SC, Brazil. Source: Authors, taken during fieldwork, December 2020.

As it is a small municipality in territorial extension and with its entire territory classified as an urban area, the main reason for the construction of such skyscrapers in Balneário Camboriú is the lack of space. This is a consequence of the area's reliance on tourists because, if there were nowhere to accommodate them all, they would seek to travel to other beaches and, if the city did not allow such high buildings, it would grow horizontally, leading to the deforestation of native forests, which are under law protection [50].

\subsection{Climate Data Collection and Processing}

In order to acquire the data on $\mathrm{Ta}$ and $\mathrm{RH}$ at the waterfront and the intra-urban zone of the coastal strip of Balneário Camboriú (the first avenue parallel to the coast), the mobile transect methodology [51] was employed partially and in an adapted manner, based on simultaneously obtaining climate data along predetermined routes within the urban network. For this study, two vehicles were used for the predetermined routes at the time of the maximum occurrence of negative radiation balance.

For data capture, the routes were traveled at an average speed of 20 to $30 \mathrm{~km} / \mathrm{h}$, and at $40 \mathrm{~km} / \mathrm{h}$ at the fasted, as speed above this value impairs the spatial resolution of micrometeorological observations, and speeds below this value can generate conflicts and disrupt local traffic with vehicles circulating in the monitoring unit, as reported by [52,53]. However, at the time of this mobile transect, there was no traffic in the area.

Two transects were established: one through Atlântica Avenue (carried out in the south-north direction) and the other through Brasil Avenue (in the north-south direction) of the waterfront of Balneário Camboriú, SC. The north-south route had a distance of $6.7 \mathrm{~km}$, while the south-north transect had a distance of $5.9 \mathrm{~km}$, as per the map in Figure 3.

Data collection occurred on 26 August 2019, in the winter period in the Southern Hemisphere, at 06:00:00 a.m., which is the period of maximum negative radiation balance, with no alterations in altitude in the area travelled by the mobile transects, i.e., they always remained at sea level. Four thermo-hygrometers with digital storage of model Instrutherm HT 500 were used and configured to make records every $30 \mathrm{~s}$ of the Ta and RH. It was considered that this record interval could better capture the variation in the climate elements and their controls along the transect. 


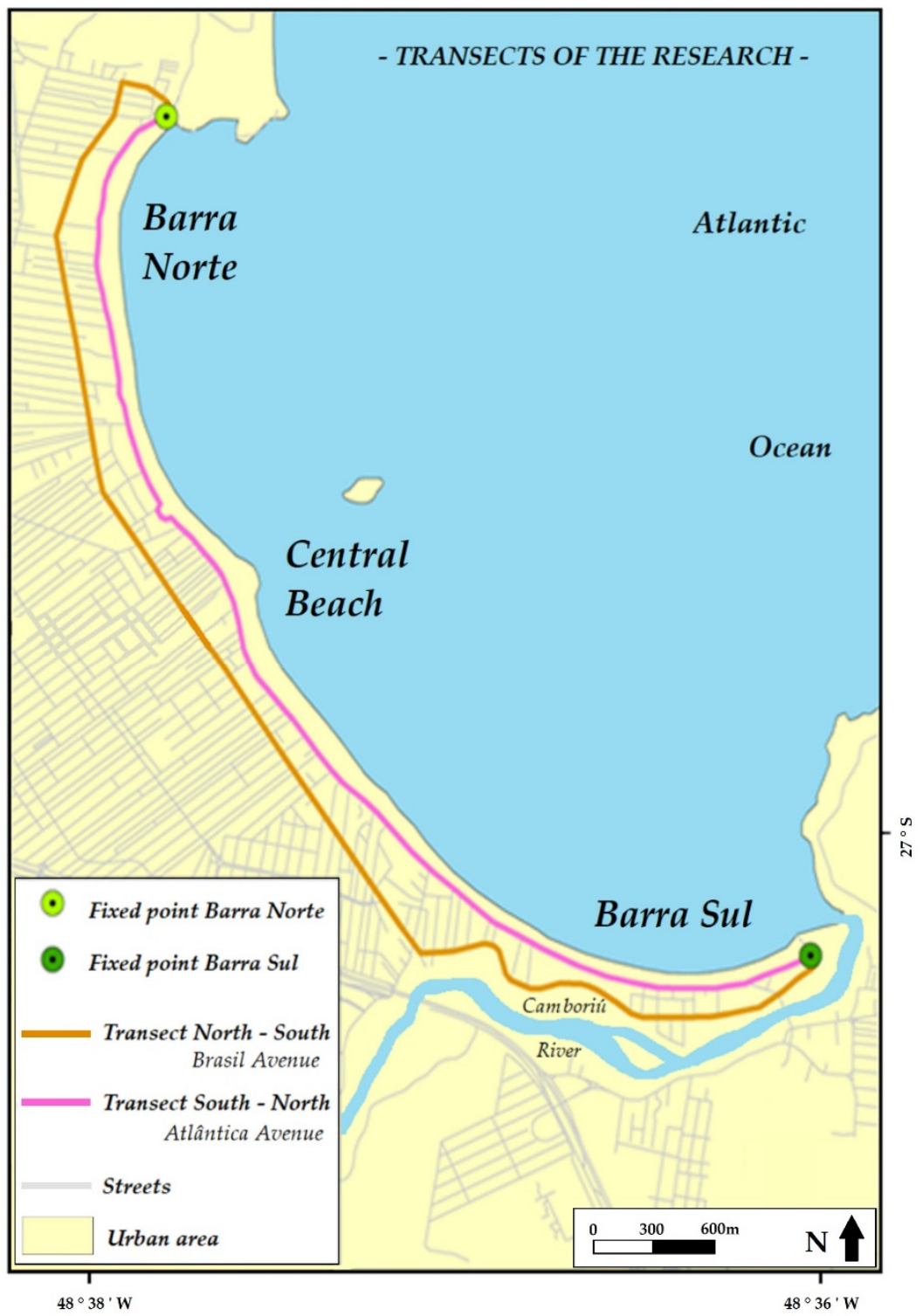

Figure 3. Map of the mobile transects carried out in the urban area of Balneário Camboriú/SC, on 26 August 2019, at 06:00:00 a.m.

To increase the reliability of the data collected during the route, two meteorological shelters (Figure 4A) were installed containing dataloggers Instrutherm HT 500 (Figure 4B), concurrently measuring every $30 \mathrm{~s}$. One was positioned at the starting point and the other at the endpoint of each mobile transect, with one being in the Barra Norte neighborhood and the other in the Barra Sul neighborhood. Such meteorological shelters, reasoned by [54,55], have been used by several research studies conducted in the Laboratory of Climatology in Subtropical Environments (LACAS) based in the Federal University of Santa Maria (UFSM). Additionally, installed at the south point (Barra Sul) was a thermo-hygro-anemometerbarometer of model ABH 4224 Instrutherm (Figure 4C), used to measure wind speed every $5 \mathrm{~s}$ and the atmospheric pressure. 


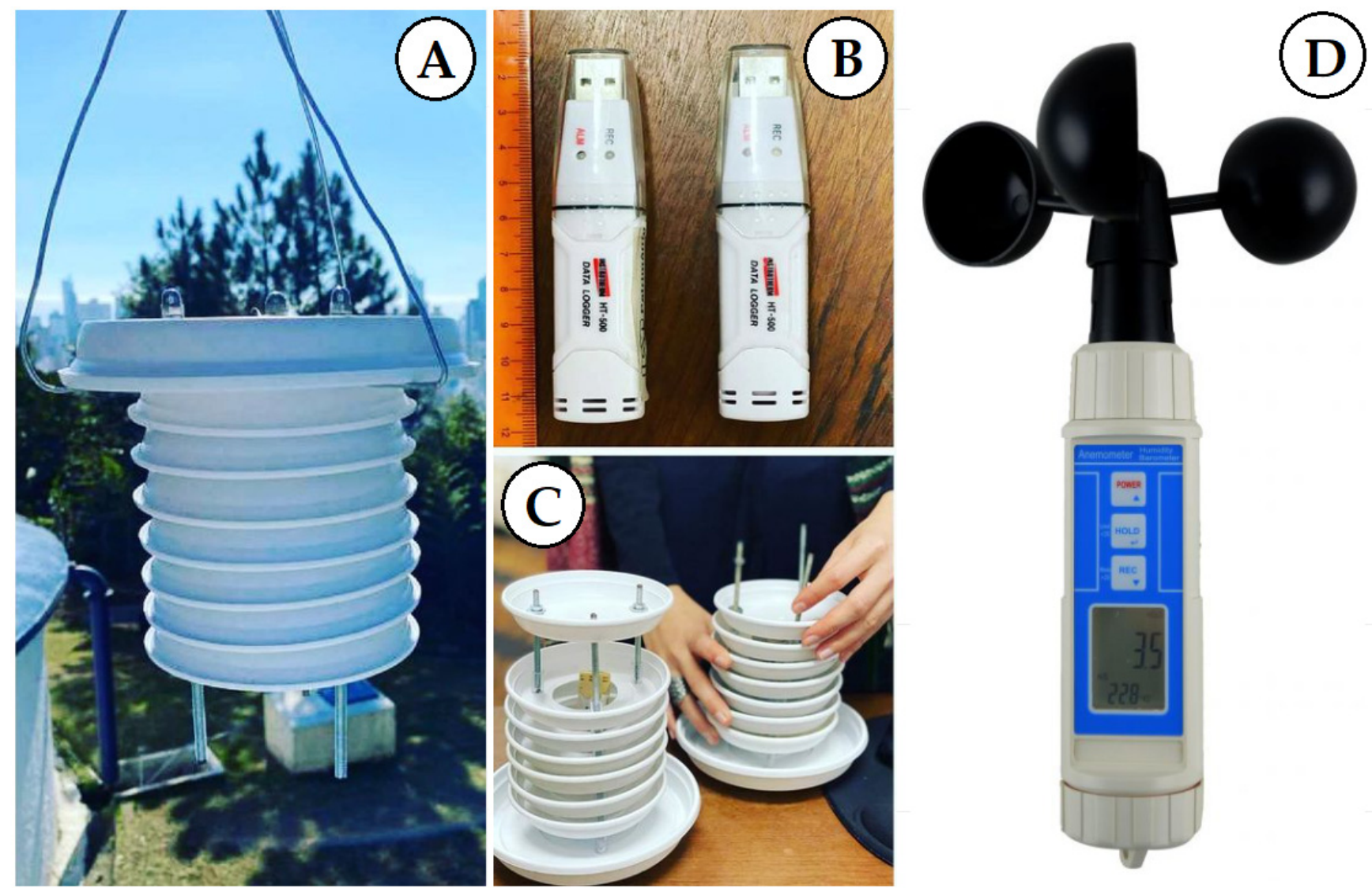

Figure 4. Meteorological shelter (A); dataloggers Instrutherm HT 500 (B); preparation of the meteorological shelter with the datalogger inside it (C); and the thermo-hygro-anemometer-barometer (D).

After we performed the mobile transects and collected the data at the two fixed points, the primary data were tabulated and analyzed in Microsoft Excel 2016 spreadsheets and exported to Geographic Information System Surfer 8.0 in order to devise thermal and hygrometric variability cartograms [56] of the coastal and intraurban zones of Balneário Camboriú/SC. The interpolation method used in the production of the cartograms was the ordinary kriging in Surfer, as advised by $[57,58]$, and the final edition of the maps was carried out with the aid of software ArcGIS 10.5, licensed to the Department of Geosciences of the UFSM.

\subsection{Remote Sensing Data Collection and Processing}

Surface temperature estimated maps and the Normalized Difference Vegetation Index (NDVI) were prepared, and the satellite images acquired through the United States Geological Survey (USGS) [59-61] using Landsat 5 TM (Thematic Mapper) and Landsat 8 TIRS (Thermal Infrared) sensors were used. Sensor)/OLI-Land Imager Operational, on the day the mobile transect was carried out (26 August 2019), but at 9 a.m. The images were processed and made available with a spatial resolution of $30 \mathrm{~m}$.

In the Geographic Information System, the bands were projected for the SIRGAS UTM $23 S$ datum and the cut for the study area was performed. Then, for the extraction of thermal data, we used the considerations of $[45,46,62]$.

\section{Results}

\subsection{Climate Conditions and Spatial Variability}

The latitude of Balneário Camboriú is $26^{\circ} 59^{\prime} 42^{\prime \prime}$ S; thus, it is at a subtropical latitude, but is situated less than $4^{\circ}$ below the Tropic of Capricorn (Figure 1), which gives it both 
tropical and subtropical climate characteristics. Regarding the monthly variation in the solar radiation at this latitude $[63,64]$, Table 1 and Figure 5 show the balance between shortwave (from the Sun) and longwave (terrestrial radiation) for the study area.

Table 1. Monthly variation of the short and longwave solar radiation in Balneário Camboriú/SC $\left(\mathrm{Wh} / \mathrm{m}^{2} \cdot \mathrm{day}\right)$.

\begin{tabular}{|c|c|c|c|c|c|c|c|c|c|c|c|c|}
\hline Month & JAN & FEV & MAR & APR & MAY & JUN & JUL & AUG & SEP & OCT & NOV & $\overline{\text { DEZ }}$ \\
\hline $\begin{array}{l}\text { Shortwave } \\
\left(\mathrm{Wh} / \mathrm{m}^{2} \cdot \text { day }\right)\end{array}$ & 4290 & 4308 & 3794 & 3414 & 3155 & 2586 & 2520 & 2952 & 2043 & 2229 & 3805 & 4188 \\
\hline $\begin{array}{l}\text { Longwave } \\
\left(\mathrm{Wh} / \mathrm{m}^{2} \cdot \text { day }\right)\end{array}$ & 5000 & 4722 & 4444 & 3611 & 3333 & 2777 & 2777 & 3333 & 3611 & 4444 & 4722 & 5000 \\
\hline
\end{tabular}

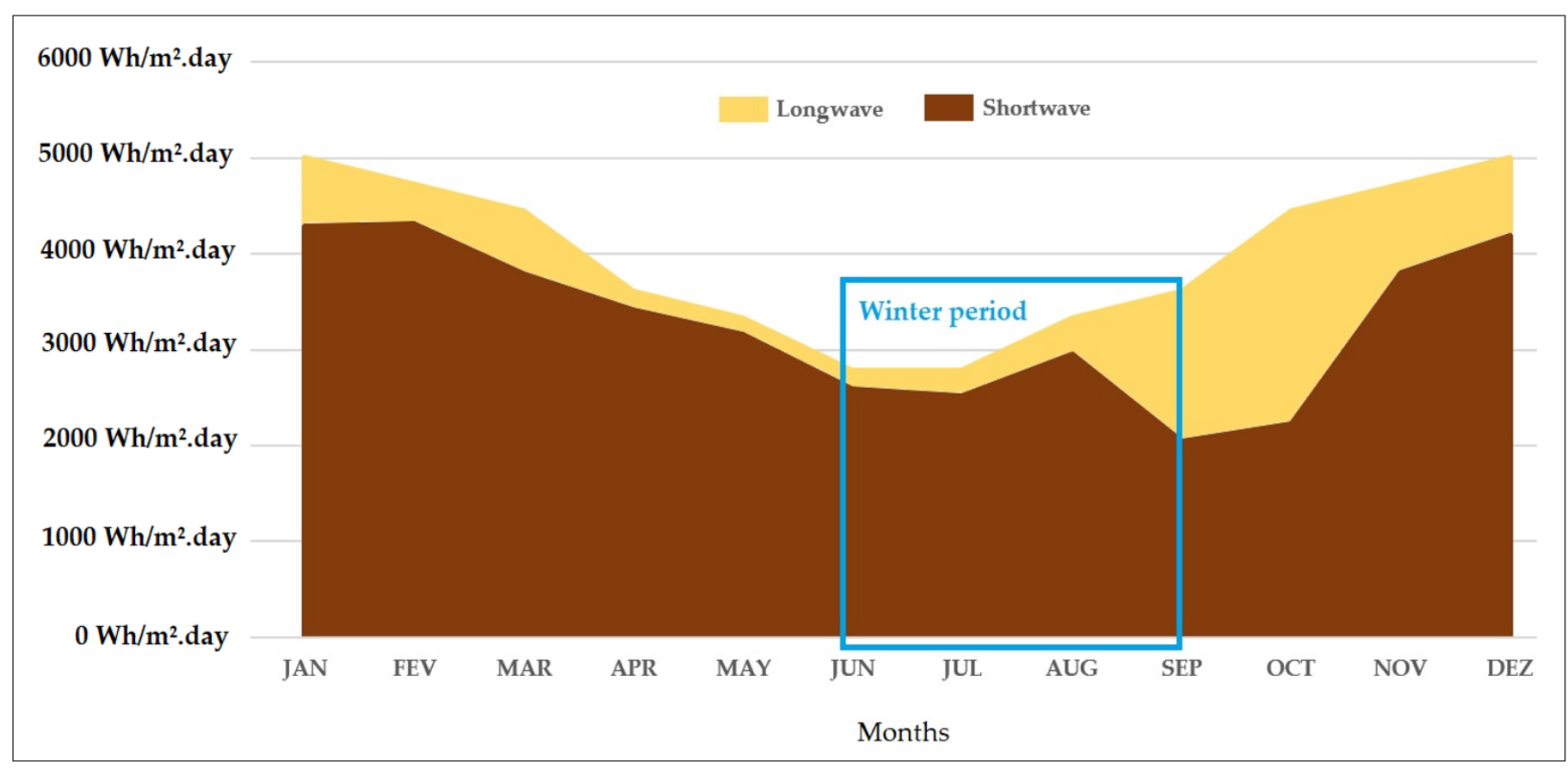

Figure 5. Monthly variation of the shortwave and longwave solar radiation in Balneário Camboriú/SC-Brazil $\left(\mathrm{Wh} / \mathrm{m}^{2}\right.$.day).

According to Figure 5, in which the winter period is highlighted, in Balneário Camboriú there is a small global balance of solar radiation, with $191 \mathrm{Wh} / \mathrm{m}^{2}$.day in June (month of the Winter Solstice), $257 \mathrm{Wh} / \mathrm{m}^{2}$.day in July, and $381 \mathrm{Wh} / \mathrm{m}^{2}$.day in August, with a greater balance of radiation in September (month of the spring equinox), with $1568 \mathrm{Wh} / \mathrm{m}^{2}$.day. In other words, August is the end of the period with the lowest global radiation balance, which justifies the choice of the date for carrying out the fieldwork.

On 26 August 2019, at 06:00:00 a.m., the weather conditions were favorable for performing the field measurements; the sky was clear and free of clouds. According to the synoptic chart, on this date, and according to the classification by [65], the Atlantic Polar Air Mass dominated. Air temperatures were relatively high, although the air was of polar origin, with moderately high $\mathrm{RH}$, which may have resulted in an increase in cloudiness throughout the day $[44,66]$ (positive radiation balance) and even precipitation, but there were clear sky nights, with the nocturnal cooling typical of situations of negative radiation balance. The data collection on the field (Table 2) enabled maps to be generated that show the specialization of the Ta and $\mathrm{RH}$ at the time of collection (Figure 6). 
Table 2. Variations of $\mathrm{Ta}\left({ }^{\circ} \mathrm{C}\right)$ and $\mathrm{RH}(\%)$ along the transects.

\begin{tabular}{cccccccccc}
\hline Transect & \multicolumn{2}{c}{ South to North } & \multicolumn{2}{c}{ North to South } & \multicolumn{2}{c}{ Transect } & \multicolumn{2}{c}{ South to North } & \multicolumn{2}{c}{ North to South } \\
\hline Time & Ta $\left({ }^{\circ} \mathbf{C}\right)$ & RH (\%) & Ta $\left({ }^{\circ} \mathbf{C}\right)$ & RH (\%) & Time & Ta $\left({ }^{\circ} \mathbf{C}\right)$ & RH $(\%)$ & Ta $\left({ }^{\circ} \mathbf{C}\right)$ & RH $(\%)$ \\
\hline 06:00:00 & 16.9 & 89.6 & 18.5 & 82.7 & $06: 09: 00$ & 16.6 & 91.8 & 16.9 \\
06:00:30 & 16.9 & 89.1 & 18.3 & 82.2 & $06: 09: 30$ & 16.6 & 91.8 & 16.9 & 89.8 \\
06:01:00 & 16.8 & 89.0 & 18.1 & 83.0 & $06: 10: 00$ & 16.7 & 91.8 & 16.9 & 89.9 \\
06:01:30 & 16.7 & 89.1 & 17.8 & 84.5 & $06: 10: 30$ & 16.7 & 91.8 & 16.8 \\
06:02:00 & 16.7 & 89.5 & 17.5 & 85.4 & $06: 11: 00$ & 16.7 & 91.8 & 16.8 \\
06:02:30 & 16.6 & 89.8 & 17.3 & 85.9 & $06: 11: 30$ & 16.7 & 91.7 & 16.8 \\
06:03:00 & 16.6 & 90.0 & 17.1 & 87.0 & $06: 12: 00$ & 16.7 & 91.7 & 16.8 \\
06:03:30 & 16.5 & 90.0 & 17.0 & 88.1 & $06: 12: 30$ & 16.7 & 91.7 & 16.7 \\
06:04:00 & 16.5 & 90.4 & 17.0 & 88.6 & $06: 13: 00$ & 16.7 & 91.6 & 16.6 \\
06:04:30 & 16.5 & 90.5 & 16.9 & 88.8 & $06: 13: 30$ & 16.6 & 91.5 & 16.5 \\
06:05:00 & 16.5 & 91.2 & 16.9 & 89.1 & $06: 14: 00$ & 16.5 & 91.1 & 16.4 \\
06:05:30 & 16.5 & 91.6 & 16.9 & 89.4 & $06: 14: 30$ & 16.5 & 90.9 & 16.3 \\
06:06:00 & 16.5 & 91.7 & 17.0 & 89.7 & $06: 15: 00$ & 16.4 & 91.1 & 16.1 \\
06:06:30 & 16.5 & 91.8 & 17.0 & 89.6 & $06: 15: 30$ & 16.4 & 91.2 & 16.3 \\
06:07:00 & 16.6 & 91.7 & 17.0 & 89.7 & $06: 16: 00$ & 16.3 & 91.1 & 16.2 \\
06:07:30 & 16.6 & 91.9 & 16.9 & 89.7 & $06: 16: 30$ & 16.3 & 91.1 & 16.2 \\
06:08:00 & 16.6 & 91.9 & 16.9 & 89.6 & $06: 17: 00$ & 16.3 & 91.1 & 90.0 \\
06:08:30 & 16.6 & 91.7 & 16.9 & 89.6 & $06: 17: 30$ & 16.3 & 91.1 & 16.3 \\
\hline
\end{tabular}

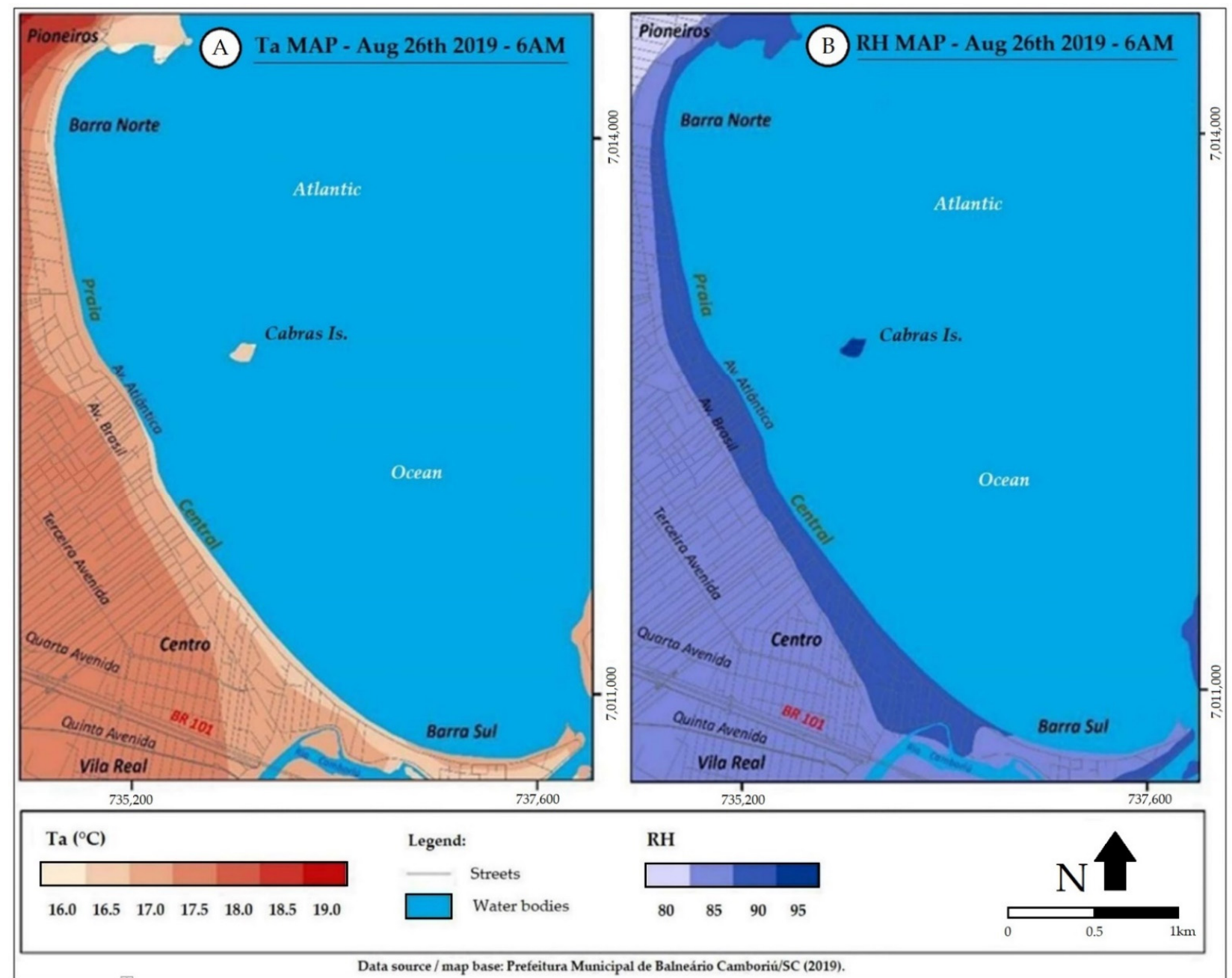

Figure 6. Spatial variability of the Ta (A) and RH (B) at the waterfront of Balneário Camboriú/SC, on 26 August 2019 between 06:00:00 and 06:17:30 (data from Table 2). 
The spatialization of Ta and RH data in areas beyond Atlântica and Brasil Avenue, such as in the neighborhoods Centro, Taquaras and Vila Real (Figure 6) are actually inferences from the mapping program, given that collections were not carried out in these areas; therefore, these data are estimated by the interpolator and are not valid. Estimated data from these areas will not be analyzed below, but only data mapped along the waterfront will be analyzed (Central Beach, Barra Norte and Barra Sul).

Upon analyzing the spatial variability in the climate elements measures on the coastal strip of Balneário Camboriú at 06:00:00 a.m. (Figure 6), we noted that the Ta recorded along the transects varied from $16.0{ }^{\circ} \mathrm{C}$ to $19.0{ }^{\circ} \mathrm{C}$ and the $\mathrm{RH}$ percentage from $80 \%$ to $95 \%$. The lowest Ta were recorded at Barra Sul, especially, and practically over the entire waterfront of the beach, presenting merely a $0.5{ }^{\circ} \mathrm{C}$ increase in the centre-north portion of Praia Central (Central Beach) along the south-north transect (highlighted in yellow in Figure 7), which is entirely on the seaside.

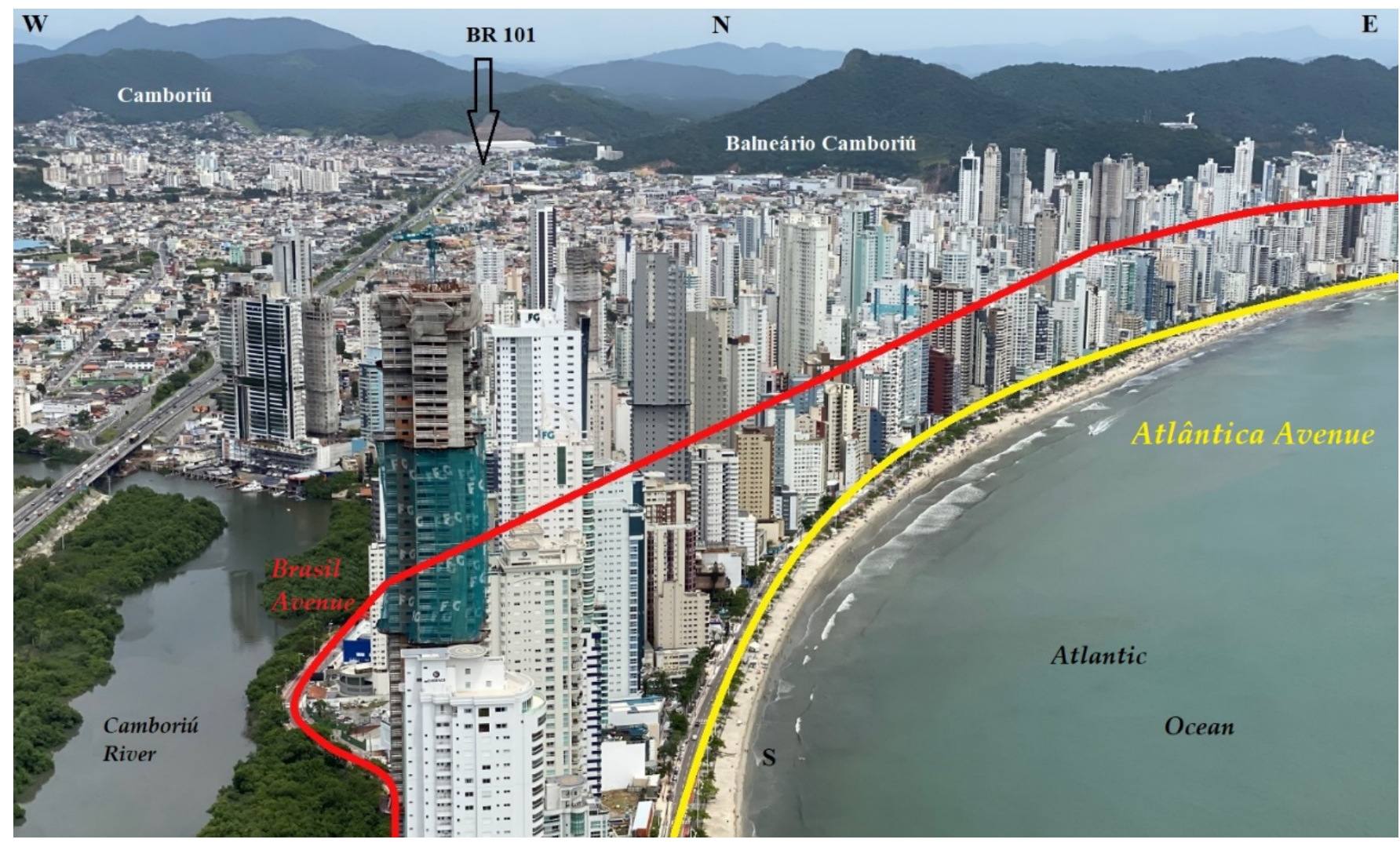

Figure 7. Sketch of the mobile transects in waterfront of Balneário Camboriú/SC. Source: Authors, taken during fieldwork, August 2019.

In turn, in the north-south transect (highlighted in red in Figure 7), there is a presence of vegetation and a large concentration of skyscrapers right at the beginning of the route, while the mouth of the Camboriú River is located at its end, at Barra Sul, where there is a strong presence of vegetation along the way and giant skyscrapers (Figure 7).

Upon examining the north-south route (highlighted in red in Figure 7), the highest temperatures recorded over the entire route are verified, with values over $17.5^{\circ} \mathrm{C}$. It is necessary to emphasize that this transect goes through Brasil Avenue (Figure 8), which is parallel to Atlântica Avenue and entirely urbanized, with little or no presence of vegetation, and the back of the largest buildings of Balneário Camboriú go along with it (the front facade of them are faced to the ocean). 

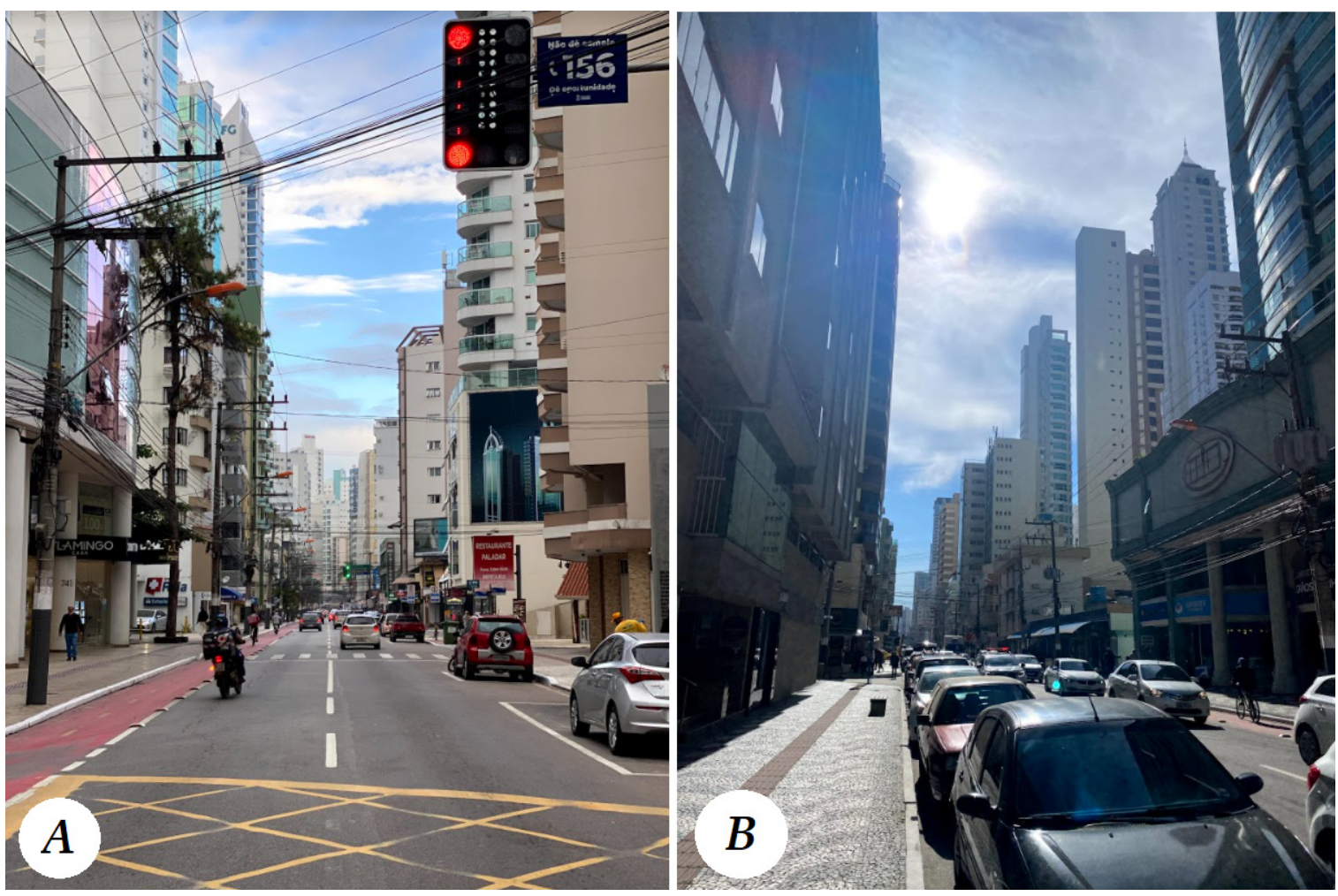

Figure 8. Images of Brasil Avenue. (A) North to south, and (B) south to north. Source: Authors, taken during fieldwork, August 2019.

At Barra Sul, by the low-cost meteorological shelter, a thermo-hygro-anemometerbarometer was installed that recorded gusts of wind over the fieldwork that varied from $0.1 \mathrm{~m} / \mathrm{s}$ to $0.5 \mathrm{~m} / \mathrm{s}$ an atmospheric pressure of $1028 \mathrm{hPa}$.

According to Figure 9, a variability in Ta and $\mathrm{RH}$ was observed between the points located at Barra Sul and Barra Norte, in a time interval that lasted from 06:00:00 a.m. to 06:17:30 a.m., i.e., during the same interval in which the mobile transects took place. The entire measuring process still occurred in a situation of negative radiation balance, still in the dark, because, on this date, the sun rose at 06:24:00 a.m., as per the field observation after the end of the measuring.

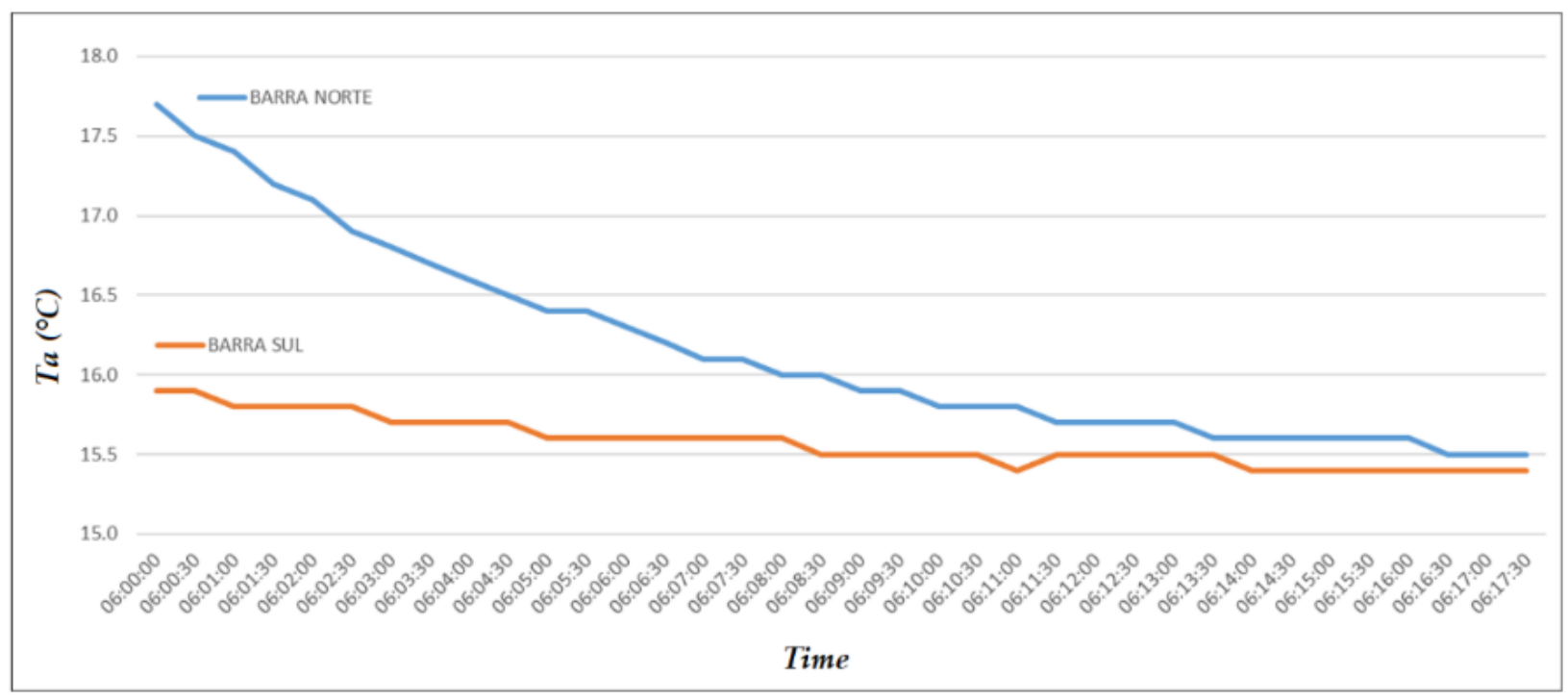

Figure 9. Chart of the Ta variability in the fixed points. 
In the chart in Figure 9, one may notice that there is a greater temperature difference at 06:00:00 a.m. compared to the following minutes (amplitude of $1.8^{\circ} \mathrm{C}$ between Barra Sul and Barra Norte) because, over the course of the performance of the transects, this thermal difference decreased due to the negative balance approximating its peak, with the difference being of only $0.1^{\circ} \mathrm{C}$ at the last collection. Therefore, one may observe that, when there is the record of the maximum negative solar energy balance (little before sunrise), there is, then, the tendency to uniform the temperature in the study area spatially and, in this sense, the land cover is not the main climate factor operating on the climate elements in this verticalized space, but rather a complement to the cooling, the origin of which is solar.

The fixed point at Barra Sul (Figure 10 B,D) presents an abundant presence of water bodies and areas with exposed soil (land plots without any type of construction) and is located next to the mouth and margins of the Camboriú River. This portion of the city is in a phase of the consolidation of large skyscrapers, the tallest buildings in Brazil. In turn, considering the data collection point located at Barra Norte (Figure 10A,C), it presents a structure different from that of the point located at Barra Sul. In addition to a green area and a hill to the north, it presents many skyscrapers in small alleys.
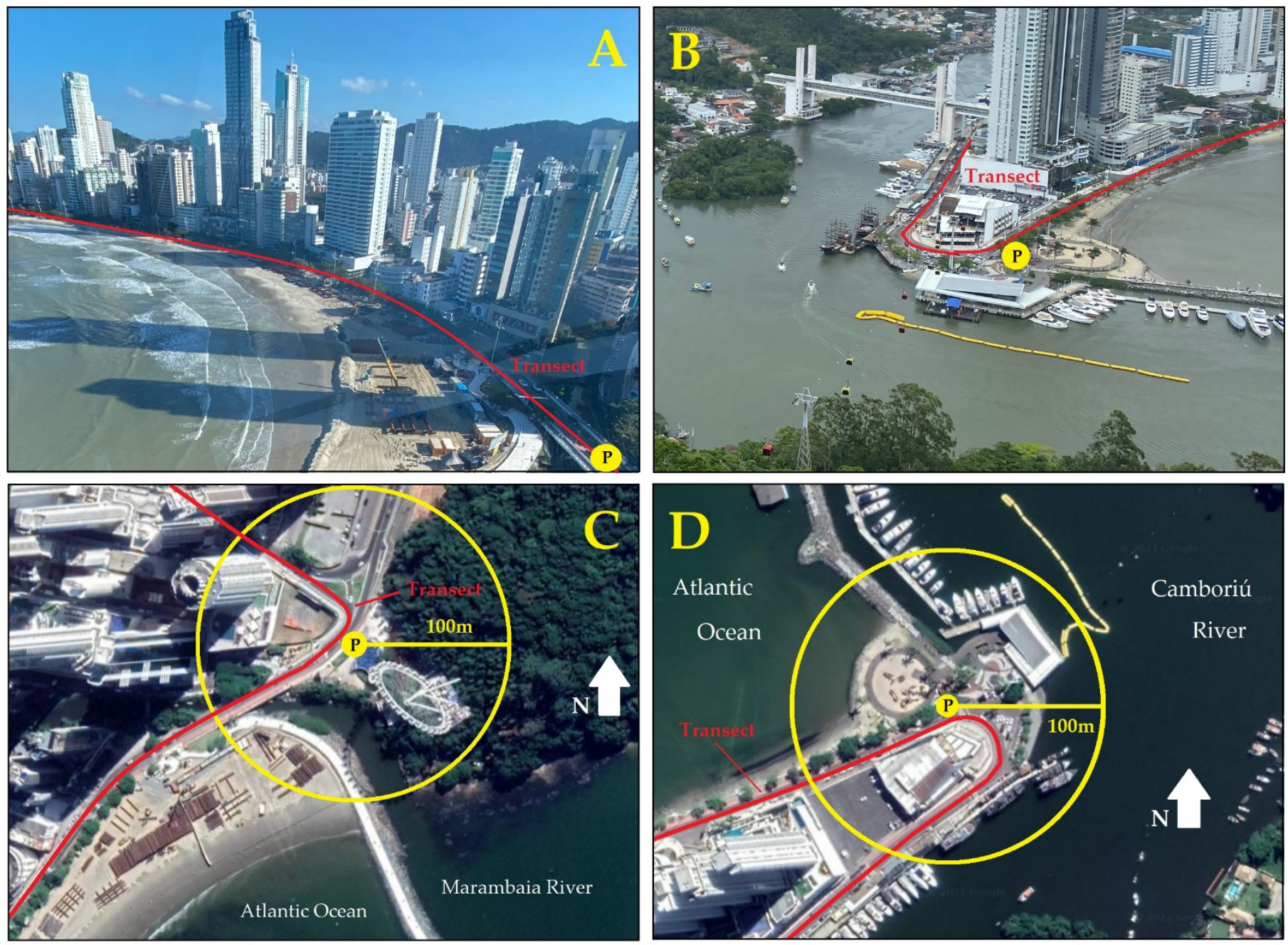

Figure 10. Barra Norte Point (A,C) and Barra Sul Point (B,D), according to Figure 3.

At 6:00 a.m., the Ta was recorded as $17.7^{\circ} \mathrm{C}$ in Barra Norte, while the Ta value was $15.9{ }^{\circ} \mathrm{C}$ at Barra Sul; as shown in Figure 9, the Ta value at the point located at Barra Norte started to decrease gradually over the time. At 06:17:30 a.m., a Ta value of $15.5^{\circ} \mathrm{C}$ was recorded at Barra Norte and $15.4^{\circ} \mathrm{C}$ at Barra Sul. 
The relative humidity chart (Figure 11) shows that the relative humidity behaves the opposite of Ta: when the temperatures rise, the $\mathrm{RH}$ decreases.

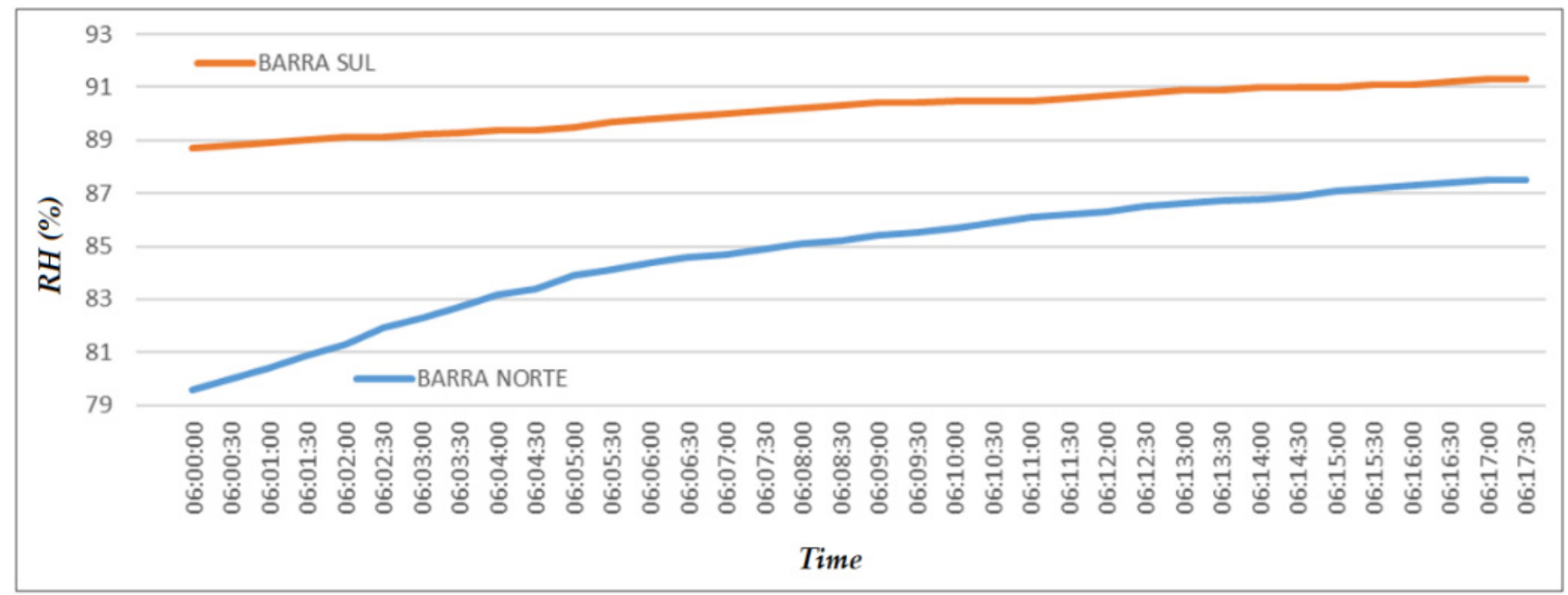

Figure 11. Chart of the variability in $\mathrm{RH}$ at the fixed points.

At 06:00:00 a.m., the amplitude between the two points was recorded at 9.1\% (Figure 11), and, at the end of the data measuring, which took place at 06:17:30 a.m., the relative humidity amplitude was $3.8 \%$. Such differences found over the data collection between the two collection points are due to the use and occupation of the land at each point and, especially, to the entry of energy in the system (positive radiation balance), causing the increase in relative humidity.

The lowest RH values recorded at both points were at 06:00:00 a.m.: 79.6\% at Barra Norte and $88.7 \%$ at Barra Sul. It was also observed that the RH at Barra Norte starts to increase over time, reaching $87.5 \%$ at 06:17:30 a.m. The same occurs at Barra Sul, yet the $\mathrm{RH}$ increases less than that at Barra Norte.

\subsection{Remote Sensing and Land Surface Temperature (LST)}

Figure 12A shows the estimated surface temperature (LST) of Balneário Camboriú for the date of 26 August 2019; however, at 9:00 a.m. (local time of the satellite in 26 August) and Figure 12B the NDVI for the study area.

After the occurrence of the minimum negative radiation balance (6:24:00 a.m.) and the consequent sunrise, the entry of solar radiation and the beginning of the positive radiation balance were responsible for the heating of the air. The surfaces that make up the urban roughness and that of the natural environment had already emitted the heat accumulated the day before, and from that moment on, they began to emit long waves after the conversion of shortwave solar radiation, starting the heating process daily, which can be seen in the comparative table of the values from Ta to $\mathrm{RH}$ at different points on the shore of Balneário Camboriú/SC (Table 3). 

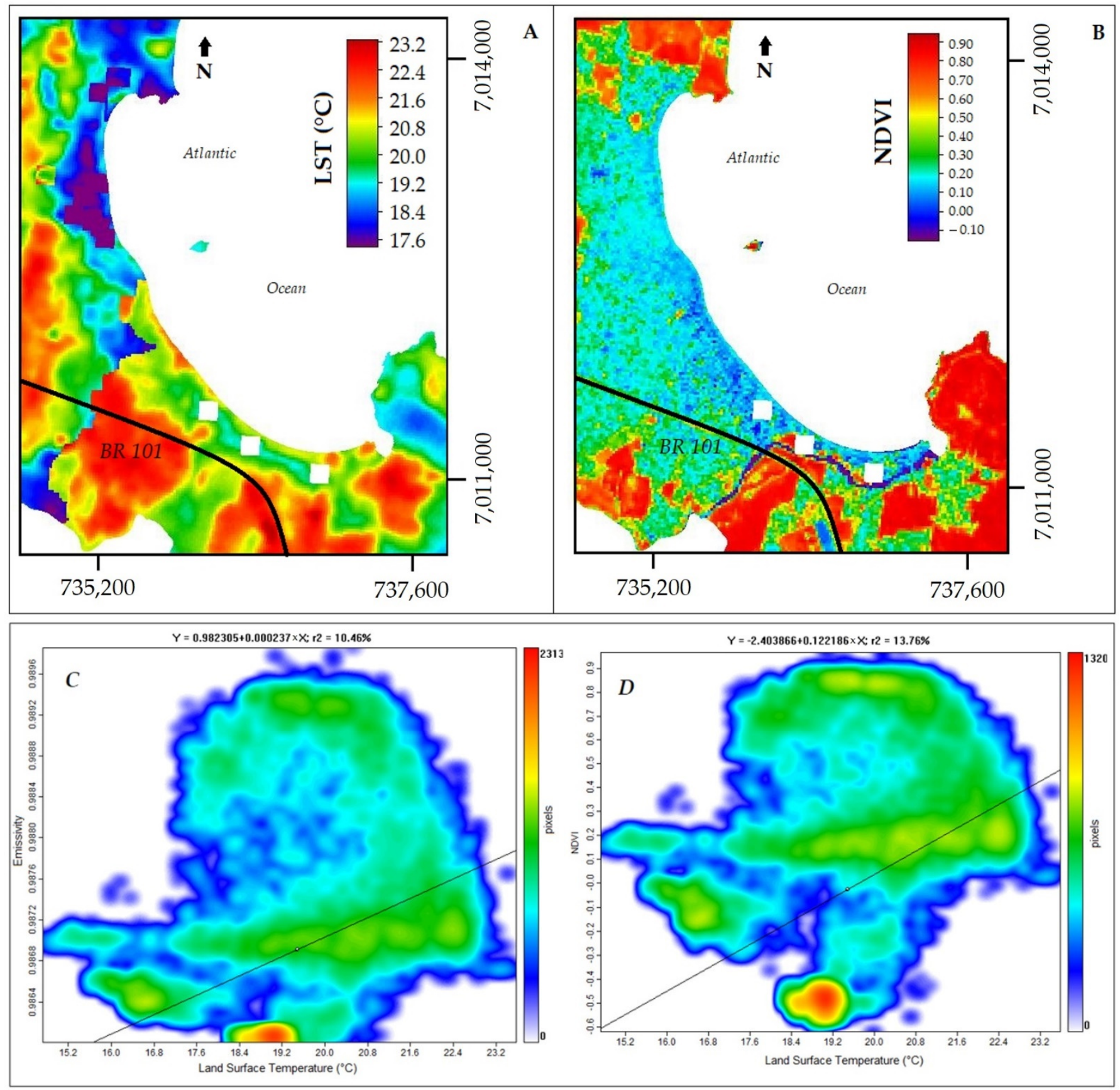

Figure 12. Land Surface Temperature estimate map (A), and NDVI map (B), for Balneário Camboriú/SC, in 26 August 2019 , at 9 a.m., and relation between emissivity and LST (C), and NDVI and LST (D).

Table 3. Ta and RH (6:30 a.m.) and LST (9 a.m.) in different points of Balneário Camboriú/SC.

\begin{tabular}{cccc}
\hline Points & Ta $\left({ }^{\circ} \mathbf{C}\right)$ & LST $\left({ }^{\circ} \mathbf{C}\right)$ & RH (\%) \\
\hline Barra Sul & 15.4 & 22.0 & 85 \\
Central Beach & 15.7 & 21.2 & 90 \\
Barra Norte & 15.5 & 19.0 & 90 \\
Brasil Ave. & 17.5 & 21.2 & 90 \\
\hline
\end{tabular}

According to Table 3, it is observed that Barra Sul, at the minimum radiation balance (6:24:00 a.m.), was the place with the lowest temperature. However, the records in Barra Norte are similar, with a slight difference in Central Beach, but with a notable difference 
on Avenida Brasil, an area with the largest urban canyon in the city $(6 \mathrm{~km}$ long). At 9:00 a.m. (local time and time of satellite imaging), already under a positive radiation balance, according to Figure 12A, the estimated surface temperature of the targets increased; however, the lowest elevation was precisely on Brasil Avenue, showing the effect of the urban canyon on the thermal variability.

The heating process in Barra Sul and Central Beach was more accentuated than in Barra Norte, and this is due to the difference in water temperature, according to image A in Figure 12. It is observed in Figure 12C that the relationships between surface emissivity, NDVI and surface temperature were higher at values close to $18.2^{\circ} \mathrm{C}$ to $19.4{ }^{\circ} \mathrm{C}$, which shows the great influence of water bodies on the air heating process on the shore of Balneário Camboriú.

\section{Discussion}

\subsection{Meteorological Conditions in Urban Area}

The variability in the climate elements in tropical and subtropical coastal cities is observed in a lot of research, such as [67-72], but parallel to the coastline (urban waterfront) it is observed in a few $[73,74]$, including solar radiation $[75,76]$, or associated with wind and thermal comfort [77], which may demonstrate the influence of the verticalization of the skyscrapers on the spatial conformation of the Ta, mainly, and RH, especially in Brazil [78]. In other words, the vertical barrier of the buildings tends to dry and warm air as one moves away from the waterfront, but the RH variations are always a result of the water content in the air (saturated content), which is a result of the performance of the upper climate scales.

Research in Urban Climatology indicates that urban canyons tend to be hotter and drier than less verticalized areas [35,79]; however, this work analyzed the urban canyon in a minimum situation of solar radiation balance, in a coastal city, with a humid subtropical climate [65], and during the winter, when the RH in southern Brazil tends to be higher [79]. In this sense, the short variation in RH (approximately 7\%) between the waterfront and Brasil Avenue is not only linked to urban microclimatic conditions, but to the regional climate condition, which is humid. Additionally, according to Figures 3, 6b and 7, the southernmost stretch of Brasil Avenue, where the Barra Sul neighbourhood is located, in addition to having greater spacing between the buildings, runs along the left brink of the Camboriú River, which can provide moisture for the canyon, provided that the regional atmospheric circulation conditions do not overlap with microclimatic conditions [65].

Verticalization makes it so that concrete surfaces have high thermal capacity [79]. This entire procedure leads to an increase in evaporation and the thermal capacity of the area [3], and the behaviors of water and soil relative to shortwave radiation are basically different [80]. Water takes longer to warm up relative to the soil [81,82], and its cooling is slower than that of the soil $[83,84]$. Such climate phenomena reported by the authors became evident in Balneário Camboriú.

\subsection{Shadow Radiation Balance}

Taking such aspects into consideration, temperature values tend to decline due to the shading that the buildings themselves cast over the surface where the temperature was measured, in addition to the negative energy balance [85,86]. The central areas present greater concentrations of buildings, and the areas with a high density of buildings are warmer and less ventilated than peripheral zones $[87,88]$. This happened at Barra Norte, even with the beginning of the positive radiation balance: the temperature tends to decrease, and it does not drop below that of the Barra Sul point due to urban densification.

The density of green spaces and water bodies is a factor that directly influences microclimates, rendering temperatures milder, the air fresher, and increasing relative humidity [89-92]. Meteorological shelters may present an error due to an instrumental difference of approximately $0.8^{\circ} \mathrm{C}$ [93]; thus, this difference in records at the end of the transect may be a mere instrument error rather than having been produced by urban roughness. 


\subsection{Land Cover and Urban Geometry}

Given the temperature data recorded at the point located at Barra Sul, such data over the collection period did not present a significant variation compared to those of the Barra Norte point, only a $0.5^{\circ} \mathrm{C}$ amplitude, the measuring difference of which may be due to a mere instrumental error and not urban roughness [93]. Where there is a large concentration of green areas or areas near large water bodies [94-96], the temperature tends to decrease [97-99]. In this sense, temperatures are lower in areas surrounding water bodies and higher in intraurban zones [100].

A greater concentration of buildings renders the ground impervious and watertight [101-103], and, for this reason, there is not a significant presence of air humidity that can dissipate the heat [104]. This can explain the variation shown in Figure 11. A water body regulates the thermal and hygrometric balance, causing the relative humidity to remain balanced [105].

However, the size of the city, its roughness and its geometry are still factors that can stand out in relation to urban land cover in terms of the definition of climate elements and their variability [106], without failing to mention the importance of synoptic circulation of higher climate scales, which will determine, on a regional scale, the thermo-hygrometric conditions of the urban environment [66], even in coastal cities with a large presence of liquid surfaces that define their energetic relationships.

\section{Conclusions}

As this was the first approach in a highly verticalized coastal city, located at a subtropical climate in Brazil, with the use of a technique of mobile transects and fixed points, it was possible to verify that there is a thermo-hygrometric variability on waterfronts in negative radiation balance.

Ta and relative humidity are related, especially, to land cover and use and the intensity of verticalization of Balneário Camboriú. This demonstrates that, in densely urbanized areas (verticalization) without the presence of vegetation, the temperature is higher and the relative humidity is lower than in locations with vegetation and water bodies. However, the moment of peak negative radiation balance tends to be the main climate control of such elements.

Therefore, at the two analyzed points, one at Barra Norte and the other at Barra Sul in Balneário Camboriú, the change in Ta and relative humidity was made evident. At Barra Norte, where the urbanization and presence of skyscrapers are more considerable, the temperature remained higher than that of Barra South, where verticalization is not so marked.

Balneário Camboriú is still developing and, over the years, in the central and Barra Sul regions, new skyscrapers will be erected that will change the urban dynamic and the local climate. Therefore, although Barra Sul presents a growing number of such buildings, the dynamic may have a more negligible impact on the observed climate elements, as they are located at the margins and mouth of the Camboriú river, the presence of which favors those temperatures do not present significant increases.

In turn, there will be a larger number of urban canyons in the central area and a higher waterfront that may likely change the local dynamic of the winds and Ta. This research was limited to surveying an episode of negative radiation balance during winter. In this sense, future and further research must be carried out in this eccentric urban environment in the Southern Hemisphere to investigate the dynamics, formation and intensity of heat islands according to different energy balances in different seasons. 
Author Contributions: Conceptualization, C.A.W. and I.L.H.; methodology, C.A.W., I.L.H., J.P.A.G., J.P.D.S., I.T.C. and J.B.; software, C.A.W. and J.P.D.S.; validation, C.A.W., J.P.D.S., I.T.C. and J.B.; formal analysis, J.P.A.G. and S.S.; investigation, C.A.W.; resources, C.A.W.; data curation, C.A.W., J.P.A.G. and J.P.D.S.; writing-original draft preparation, C.A.W. and I.L.H.; writing-review and editing, C.A.W., I.L.H., J.P.A.G. and S.S.; visualization, C.A.W., J.P.A.G. and S.S.; supervision, C.A.W., J.P.A.G. and S.S.; project administration, C.A.W.; funding acquisition, C.A.W. All authors have read and agreed to the published version of the manuscript.

Funding: This research received no external funding.

Institutional Review Board Statement: Not applicable.

Data Availability Statement: Data set available on request to corresponding authors.

Conflicts of Interest: The authors declare that they have no known competing financial interests or personal relationships that could have appeared to influence the work reported in this paper.

\section{References}

1. Amorim, M.C.D.C.T.; Dubreuil, V. Intensity of Urban Heat Islands in Tropical and Temperate Climates. Climate 2017, 5, 91. [CrossRef]

2. Roth, M. Review of urban climate research in (sub)tropical regions. Int. J. Clim. 2007, 27, 1859-1873. [CrossRef]

3. Cheung, P.K.; Jim, C. Comparing the cooling effects of a tree and a concrete shelter using PET and UTCI. Build. Environ. 2018, 130, 49-61. [CrossRef]

4. Chapman, S.; Thatcher, M.; Salazar, A.; Watson, J.E.M.; McAlpine, C.A. The Effect of Urban Density and Vegetation Cover on the Heat Island of a Subtropical City. J. Appl. Meteorol. Clim. 2018, 57, 2531-2550. [CrossRef]

5. Lu, L.; Weng, Q.; Xiao, D.; Guo, H.; Li, Q.; Hui, W. Spatiotemporal Variation of Surface Urban Heat Islands in Relation to Land Cover Composition and Configuration: A Multi-Scale Case Study of Xi'an, China. Remote Sens. 2020, 12, 2713. [CrossRef]

6. Marciotto, E.R. Impact of City Verticalization on the Urban Surface Energy Budget: A modeling study. In Proceedings of the Seventh International Conference on Urban Climate, Yokohama, Japan, 29 June-3 July 2009.

7. Zheng, Y.; Ren, C.; Xu, Y.; Wang, R.; Ho, J.; Lau, K.; Ng, E. GIS-based mapping of Local Climate Zone in the high-density city of Hong Kong. Urban Clim. 2018, 24, 419-448. [CrossRef]

8. Emmanuel, R.; Johansson, E. Influence of urban morphology and sea breeze on hot humid microclimate: The case of Colombo, Sri Lanka. Clim. Res. 2006, 30, 189-200. [CrossRef]

9. Garreau, E.; Berthou, T.; Duplessis, B.; Partenay, V.; Marchio, D. Solar shading and multi-zone thermal simulation: Parsimonious modelling at urban scale. Energy Build. 2021, 249, 111176. [CrossRef]

10. MeshkinKiya, M.; Paolini, R. Uncertainty of solar radiation in urban canyons propagates to indoor thermo-visual comfort. Sol. Energy 2021, 221, 545-558. [CrossRef]

11. Liu, Y.; Zhang, M.; Li, Q.; Zhang, T.; Yang, L.; Liu, J. Investigation on the distribution patterns and predictive model of solar radiation in urban street canyons with panorama images. Sustain. Cities Soc. 2021, 75, 103275. [CrossRef]

12. Gong, F.-Y.; Zeng, Z.-C.; Ng, E.Y.Y.; Norford, L.K. Spatiotemporal patterns of street-level solar radiation estimated using Google Street View in a high-density urban environment. Build. Environ. 2019, 148, 547-566. [CrossRef]

13. Middel, A.; Selover, N.; Hagen, B.; Chhetri, N. Impact of shade on outdoor thermal comfort-a seasonal field study in Tempe, Arizona. Int. J. Biometeorol. 2016, 60, 1849-1861. [CrossRef] [PubMed]

14. Garcia-Nevado, E.; Beckers, B.; Coch, H. Assessing the cooling effect of urban textile shading devices through time-lapse thermography. Sustain. Cities Soc. 2020, 63, 102458. [CrossRef]

15. Arkon, C.A.; Özkol, Ü. Effect of urban geometry on pedestrian-level wind velocity. Arch. Sci. Rev. 2013, 57, 4-19. [CrossRef]

16. Giridharan, R.; Lau, S.; Ganesan, S.; Givoni, B. Urban design factors influencing heat island intensity in high-rise high-density environments of Hong Kong. Build. Environ. 2007, 42, 3669-3684. [CrossRef]

17. Deng, J.-Y.; Wong, N.H. Impact of urban canyon geometries on outdoor thermal comfort in central business districts. Sustain. Cities Soc. 2020, 53, 101966. [CrossRef]

18. Stewart, I.D.; Oke, T.R. Local Climate Zones for Urban Temperature Studies. Bull. Am. Meteorol. Soc. 2012, 93, 1879-1900. [CrossRef]

19. Meng, C.; Huang, C.; Dou, J.; Li, H.; Cheng, C. Key parameters in urban surface radiation budget and energy balance modeling. Urban Clim. 2021, 39, 100940. [CrossRef]

20. Park, S.; Tuller, S.E. Advanced view factor analysis method for radiation exchange. Int. J. Biometeorol. 2013, 58, 161-178. [CrossRef]

21. Matzarakis, A.; Rutz, F.; Mayer, H. Modelling radiation fluxes in simple and complex environments-application of the RayMan model. Int. J. Biometeorol. 2007, 51, 323-334. [CrossRef]

22. Haeger-Eugensson, M.; Holmer, B. Advection caused by the urban heat island circulation as a regulating factor on the nocturnal urban heat island. Int. J. Climatol. 1999, 19, 975-988. [CrossRef]

23. Herrmann, J.; Matzarakis, A. Mean radiant temperature in idealised urban canyons—examples from Freiburg, Germany. Int. J. Biometeorol. 2011, 56, 199-203. [CrossRef] 
24. Kwon, Y.J.; Lee, D.K.; Kim, J.-H.; Oh, K. Improving urban thermal environments by analysing sensible heat flux patterns in zoning districts. Cities 2021, 116, 103276. [CrossRef]

25. Lindberg, F.; Holmer, B.; Thorsson, S. SOLWEIG 1.0 Modelling spatial variations of 3D radiant fluxes and mean radiant temperature in complex urban settings. Int. J. Biometeorol. 2008, 52, 697-713. [CrossRef] [PubMed]

26. Choi, Y.; Lee, S.; Moon, H. Urban Physical Environments and the Duration of High Air Temperature: Focusing on Solar Radiation Trapping Effects. Sustainability 2018, 10, 4837. [CrossRef]

27. Lee, K.; Levermore, G.J. Sky view factor and sunshine factor of urban geometry for urban heat island and renewable energy. Arch. Sci. Rev. 2018, 62, 26-34. [CrossRef]

28. Aoyagi, T.; Seino, N. A Square Prism Urban Canopy Scheme for the NHM and Its Evaluation on Summer Conditions in the Tokyo Metropolitan Area, Japan. J. Appl. Meteorol. Clim. 2011, 50, 1476-1496. [CrossRef]

29. Chow, W.T.L.; Roth, M. Temporal dynamics of the urban heat island of Singapore. Int. J. Clim. 2006, 26, 2243-2260. [CrossRef]

30. Giridharan, R.; Lau, S.; Ganesan, S. Nocturnal heat island effect in urban residential developments of Hong Kong. Energy Build. 2005, 37, 964-971. [CrossRef]

31. Li, D.; Sun, T.; Liu, M.; Yang, L.; Wang, L.; Gao, Z. Contrasting responses of urban and rural surface energy budgets to heat waves explain synergies between urban heat islands and heat waves. Environ. Res. Lett. 2015, 10, 054009. [CrossRef]

32. Liu, R.; Han, Z.; Wu, J.; Hu, Y.; Li, J. The impacts of urban surface characteristics on radiation balance and meteorological variables in the boundary layer around Beijing in summertime. Atmos. Res. 2017, 197, 167-176. [CrossRef]

33. Nichol, J. Remote Sensing of Urban Heat Islands by Day and Night. Photogramm. Eng. Remote Sens. 2005, 71, 613-621. [CrossRef]

34. Cui, W.; Chui, T.F.M. Measurements and simulations of energy fluxes over a high-rise and compact urban area in Hong Kong. Sci. Total Environ. 2021, 765, 142718. [CrossRef]

35. Ali-Toudert, F. Exploration of the thermal behaviour and energy balance of urban canyons in relation to their geometrical and constructive properties. Build. Environ. 2021, 188, 107466. [CrossRef]

36. Conejo-Fernández, J.; Cappelletti, F.; Gasparella, A. Including the effect of solar radiation in dynamic indoor thermal comfort indices. Renew. Energy 2021, 165, 151-161. [CrossRef]

37. Fischereit, J. The simple urban radiation model for estimating mean radiant temperature in idealised street canyons. Urban Clim. 2021, 35, 100694. [CrossRef]

38. Carvalho, H.D.; Chang, B.; McInnes, K.J.; Heilman, J.L.; Wherley, B.; Aitkenhead-Peterson, J.A. Energy balance and temperature regime of different materials used in urban landscaping. Urban Clim. 2021, 37, 100854. [CrossRef]

39. Ge, X.; Mauree, D.; Castello, R.; Scartezzini, J.-L. Spatio-Temporal Relationship between Land Cover and Land Surface Temperature in Urban Areas: A Case Study in Geneva and Paris. ISPRS Int. J. Geo-Inf. 2020, 9, 593. [CrossRef]

40. Fernández, M.E.; Picone, N.; Gentili, J.O.; Campo, A.M. Analysis of the Urban Energy Balance in Bahía Blanca (Argentina). Urban Clim. 2021, 37, 100856. [CrossRef]

41. Wetherley, E.B.; Roberts, D.A.; Tague, C.L.; Jones, C.; Quattrochi, D.A.; McFadden, J.P. Remote sensing and energy balance modeling of urban climate variability across a semi-arid megacity. Urban Clim. 2021, 35, 100757. [CrossRef]

42. Chow, W.T.L.; Volo, T.J.; Vivoni, E.R.; Jenerette, G.D.; Ruddell, B.L. Seasonal dynamics of a suburban energy balance in Phoenix, Arizona. Int. J. Clim. 2014, 34, 3863-3880. [CrossRef]

43. Kawai, T.; Kanda, M. Urban Energy Balance Obtained from the Comprehensive Outdoor Scale Model Experiment. Part I: Basic Features of the Surface Energy Balance. J. Appl. Meteorol. Clim. 2010, 49, 1341-1359. [CrossRef]

44. Kejna, M.; Uscka-Kowalkowska, J.; Kejna, P. The influence of cloudiness and atmospheric circulation on radiation balance and its components. Theor. Appl. Clim. 2021, 144, 823-838. [CrossRef]

45. Nichol, J.E.; Fung, W.Y.; Lam, K.-S.; Wong, M.S. Urban heat island diagnosis using ASTER satellite images and 'in situ' air temperature. Atmos. Res. 2009, 94, 276-284. [CrossRef]

46. Rasul, A.; Balzter, H.; Smith, C.; Remedios, J.; Adamu, B.; Sobrino, J.A.; Srivanit, M.; Weng, Q. A Review on Remote Sensing of Urban Heat and Cool Islands. Land 2017, 6, 38. [CrossRef]

47. Schlickmann, M. Do Arraial do Bom Sucesso a Balneário Camboriú: Mais de 50 anos de História, 1st ed.; Fundação Cultural de Balneário Camboriú: Balneário Camboriú, Brazil, 2016; 83p.

48. IBGE. Available online: https://cidades.ibge.gov.br/brasil/sc/balneario-camboriu/panorama (accessed on 17 August 2021).

49. Wollmann, C.A.; Gobo, J.P.A.; Chiquetto, J.P.; Shooshtarian, S.; Rotili Junior, D.H. Balneário Camboriú: The "Brazilian Dubai" and the Greatest Verticalization Process in the Southern Hemisphere. Bulletin of International Association for Urban Climate. 2020. Issue No. 78. Available online: http:/ / www.urban-climate.org/wp-content/uploads/newsletter/IAUC078.pdf (accessed on 15 September 2021).

50. Campos, G.D.A.C.; Júnior, E.F.C. Sombreamento causado pelos edifícios altos em curitiba. Cad. Arquitetura Urban 2016, $22,26$. [CrossRef]

51. Taha, H.; Levinson, R.; Mohegh, A.; Gilbert, H.; Ban-Weiss, G.; Chen, S. Air-Temperature Response to Neighborhood-Scale Variations in Albedo and Canopy Cover in the Real World: Fine-Resolution Meteorological Modeling and Mobile Temperature Observations in the Los Angeles Climate Archipelago. Climate 2018, 6, 53. [CrossRef]

52. Sun, C.-Y.; Brazel, A.J.; Chow, W.; Hedquist, B.C.; Prashad, L. Desert heat island study in winter by mobile transect and remote sensing techniques. Theor. Appl. Clim. 2009, 98, 323-335. [CrossRef] 
53. Rodríguez, L.R.; Ramos, J.S.; de la Flor, F.J.S.; Domínguez, S. Álvarez Analyzing the urban heat Island: Comprehensive methodology for data gathering and optimal design of mobile transects. Sustain. Cities Soc. 2020, 55, 102027. [CrossRef]

54. Hoppe, I.L.; Iensse, A.C.; Simioni, J.P.D.; Wollmann, C.A. Comparação entre um abrigo meteorológico de baixo custo e a estação meteorológica oficial no INMET, em Santa Maria (RS). Ciência Nat. 2015, 37, 132-137. [CrossRef]

55. Baratto, J.; Galvani, E.; Wollmann, C.A. Calibração e desempenho do abrigo meteorológico de baixo custo em condições de campo. Rev. Bras. Clim. 2020, 26, 441-456. [CrossRef]

56. Wollmann, C.A.; Galvani, E. Zoneamento Agroclimático Aportes Teóricos, Metodológicos e Técnicas para o Estudo das Roseiras (Rosaceae spp.) no Rio Grande do Sul, 1st ed.; Buqui Livros Digitais: Porto Alegre, Brazil, 2014; Volume 1, 149p.

57. Boer, E.P.; de Beurs, K.M.; Hartkamp, A.D. Kriging and thin plate splines for mapping climate variables. Int. J. Appl. Earth Obs. Geoinf. 2001, 3, 146-154. [CrossRef]

58. Aalto, J.; Pirinen, P.; Heikkinen, J.; Venäläinen, A. Spatial interpolation of monthly climate data for Finland: Comparing the performance of kriging and generalized additive models. Theor. Appl. Clim. 2013, 112, 99-111. [CrossRef]

59. USGS. Available online: http://landsat.usgs.gov//18handbook_section1.php (accessed on 15 August 2021).

60. USGS. Available online: https://www.usgs.gov/core-science-systems/nli/landsat/landsat-collection-2-level-1-data?qt-science_ support_page_related_con=1\#qtscience_support_page_related_con (accessed on 15 August 2021).

61. USGS. Available online: https://www.usgs.gov/core-science-systems/nli/landsat/landsat-collection-2?qtscience_support_ page_related_con=1\#qt-science_support_page_related_con (accessed on 15 August 2021).

62. Chander, G.; Markham, B.L.; Helder, D.L. Summary of current radiometric calibration coefficients for Landsat MSS, TM, ETM+, and EO-1 ALI sensors. Remote Sens. Environ. 2009, 113, 893-903. [CrossRef]

63. Pereira, E.B.; Martins, F.R.; Gonçalves, A.R.; Costa, R.S.; De Lima, F.J.L.; Rüther, R.; Abreu, S.D.L.; Tiepolo, G.M.; Pereira, S.V.; De Souza, J.G. Atlas Brasileiro de Energia Solar. 2017, Volume 80. Available online: https:/ / cenariossolar.editorabrasilenergia com.br/wp-content/uploads/sites/8/2020/11/Atlas_Brasileiro_Energia_Solar_2a_Edicao_compressed.pdf (accessed on 15 August 2021).

64. Tiba, C.; Fraidenraich, N.; Moszkowicz, M.; Cavalcant, E.S.C.; Lyra, F.J.M.; Nogueira, A.M.B.; Gallegos, H.G.; Araújo, D.C.N.; Mamede, F.J.S.; Pinho Júnior, A.F.; et al. Atlas Solarimétrico do Brasil: Banco de Dados Solarimétricos; Editora Universitária da UFPE: Recife, Brazil, 2000; 111p. Available online: http://www.cresesb.cepel.br/publicacoes/download/atlas_solarimetrico_do_brasil_ 2000.pdf (accessed on 13 October 2021).

65. Sartori, M.G.B. Vento Norte, 1st ed.; Palotti: Santa Maria, Brazil, 2016; 256p.

66. Khan, H.S.; Santamouris, M.; Kassomenos, P.; Paolini, R.; Caccetta, P.; Petrou, I. Spatiotemporal variation in urban overheating magnitude and its association with synoptic air-masses in a coastal city. Sci. Rep. 2021, 11, 6762. [CrossRef]

67. Founda, D.; Pierros, F.; Petrakis, M.; Zerefos, C. Interdecadal variations and trends of the Urban Heat Island in Athens (Greece) and its response to heat waves. Atmos. Res. 2015, 161-162, 1-13. [CrossRef]

68. Ghadban, M.; Baayoun, A.; Lakkis, I.; Najem, S.; Saliba, N.A.; Shihadeh, A. A novel method to improve temperature forecast in data-scarce urban environments with application to the Urban Heat Island in Beirut. Urban Clim. 2020, 33, 100648. [CrossRef]

69. Shafaghat, A.; Manteghi, G.; Keyvanfar, A.; Bin Lamit, H.; Saito, K.; Ossen, D.R. Street Geometry Factors Influence Urban Microclimate in Tropical Coastal Cities: A Review. Environ. Clim. Technol. 2016, 17, 61-75. [CrossRef]

70. Iping, A.; Kidston-Lattari, J.; Simpson-Young, A.; Duncan, E.; McManus, P. (Re)presenting urban heat islands in Australian cities: A study of media reporting and implications for urban heat and climate change debates. Urban Clim. 2019, 27, 420-429. [CrossRef]

71. Giannaros, T.M.; Melas, D. Study of the urban heat island in a coastal Mediterranean City: The case study of Thessaloniki, Greece. Atmos. Res. 2012, 118, 103-120. [CrossRef]

72. Mandelmilch, M.; Ferenz, M.; Mandelmilch, N.; Potchter, O. Urban Spatial Patterns and Heat Exposure in the Mediterranean City of Tel Aviv. Atmosphere 2020, 11, 963. [CrossRef]

73. Song, X.; Liu, J.; Zhao, Y. Effect of design factors on the thermal environment in the waterfront area. Procedia Eng. 2017, 205, 2677-2682. [CrossRef]

74. Lan, H.; Lau, K.K.-L.; Shi, Y.; Ren, C. Improved urban heat island mitigation using bioclimatic redevelopment along an urban waterfront at Victoria Dockside, Hong Kong. Sustain. Cities Soc. 2021, 74, 103172. [CrossRef]

75. Daramola, M.T.; Balogun, I.A. Local climate zone classification of surface energy flux distribution within an urban area of a hot-humid tropical city. Urban Clim. 2019, 29, 100504. [CrossRef]

76. Paolini, R.; Mainini, A.G.; Poli, T.; Vercesi, L. Assessment of Thermal Stress in a Street Canyon in Pedestrian Area with or without Canopy Shading. Energy Procedia 2014, 48, 1570-1575. [CrossRef]

77. Johansson, E.; Yahia, M.W. Wind comfort and solar access in a coastal development in Malmö, Sweden. Urban Clim. 2020, 33, 100645. [CrossRef]

78. Barbosa, G.S.; Drach, P.R.C.; Corbella, O.D. Intraurban Temperature Variations: Urban Morphologies of the Densification Process of Copacabana Neighborhood, Brazil. Climate 2019, 7, 65. [CrossRef]

79. Firdausah, A.M.; Wonorahardjo, S. Typology Study of Urban Canyon in Residential Area and The Quality of Its Thermal Environment. IOP Conf. Ser. Earth Environ. Sci. 2018, 152, 012025. [CrossRef]

80. Dantas, D.; Barbosa, G.P.; Cunha, E.G.S.; Souza, M.J.H.; Souza, C.M.; Davidson, E.A.; And Janssens, I.A. Temperature sensitivity of soil carbon decomposition and feedbacks to climate change. Nature 2006, 440, 165-173. Available online: https://www.nature. com/articles/nature04514.pdf (accessed on 15 August 2021). 
81. Saaroni, H.; Ziv, B. The impact of a small lake on heat stress in a Mediterranean urban park: The case of Tel Aviv, Israel. Int. J. Biometeorol. 2003, 47, 156-165. [CrossRef]

82. Gupta, N.; Mathew, A.; Khandelwal, S. Analysis of cooling effect of water bodies on land surface temperature in nearby region: A case study of Ahmedabad and Chandigarh cities in India. Egypt. J. Remote Sens. Space Sci. 2019, 22, 81-93. [CrossRef]

83. Syafii, N.I.; Ichinose, M.; Wong, N.H.; Kumakura, E.; Jusuf, S.K.; Chigusa, K. Experimental Study on the Influence of Urban Water Body on Thermal Environment at Outdoor Scale Model. Procedia Eng. 2016, 169, 191-198. [CrossRef]

84. Zhang, Q.; Wu, Z.; Guo, G. The cooling effect of water landscape in high-density urban built-up area case study of the center urban district of guangzhou. In Proceedings of the 2017 2nd International Conference on Frontiers of Sensors Technologies (ICFST), Shenzhen, China, 14-16 April 2017; pp. 394-400.

85. Wong, M.S.; Nichol, J.E.; To, P.H.; Wang, J. A simple method for designation of urban ventilation corridors and its application to urban heat island analysis. Build. Environ. 2010, 45, 1880-1889. [CrossRef]

86. Cheung, P.K.; Jim, C. Effects of urban and landscape elements on air temperature in a high-density subtropical city. Build. Environ. 2019, 164, 106362. [CrossRef]

87. Shih, W.-Y.; Ahmad, S.; Chen, Y.C.; Lin, T.-P.; Mabon, L. Spatial relationship between land development pattern and intra-urban thermal variations in Taipei. Sustain. Cities Soc. 2020, 62, 102415. [CrossRef]

88. Takkanon, P.; Chantarangul, P. Effects of urban geometry and green area on thermal condition of urban street canyons in Bangkok. Arch. Sci. Rev. 2019, 62, 35-46. [CrossRef]

89. Ha, J.; Choi, Y.; Lee, S.; Oh, K. Diurnal and Seasonal Variations in the Effect of Urban Environmental Factors on Air Temperature: A Consecutive Regression Analysis Approach. Int. J. Environ. Res. Public Health 2020, 17, 421. [CrossRef]

90. Maheng, D.; Ducton, I.; Lauwaet, D.; Zevenbergen, C.; Pathirana, A. The Sensitivity of Urban Heat Island to Urban Green Space-A Model-Based Study of City of Colombo, Sri Lanka. Atmosphere 2019, 10, 151. [CrossRef]

91. Cheung, P.K.; Jim, C. Differential cooling effects of landscape parameters in humid-subtropical urban parks. Landsc. Urban Plan. 2019, 192, 103651. [CrossRef]

92. Amani-Beni, M.; Zhang, B.; Xie, G.-D.; Shi, Y. Impacts of Urban Green Landscape Patterns on Land Surface Temperature: Evidence from the Adjacent Area of Olympic Forest Park of Beijing, China. Sustainability 2019, 11, 513. [CrossRef]

93. Yang, J.; Liu, Q.; Dai, W.; Ding, R. Fluid dynamic design and experimental study of an aspirated temperature measurement platform used in climate observation. Rev. Sci. Instrum. 2016, 87, 84503. [CrossRef] [PubMed]

94. Spronken-Smith, R.; Oke, T.R. The thermal regime of urban parks in two cities with different summer climates. Int. J. Remote Sens. 1998, 19, 2085-2104. [CrossRef]

95. Lee, H.; Mayer, H.; Chen, L. Contribution of trees and grasslands to the mitigation of human heat stress in a residential district of Freiburg, Southwest Germany. Landsc. Urban Plan. 2016, 148, 37-50. [CrossRef]

96. Konarska, J.; Holmer, B.; Lindberg, F.; Thorsson, S. Influence of vegetation and building geometry on the spatial variations of air temperature and cooling rates in a high-latitude city. Int. J. Clim. 2016, 36, 2379-2395. [CrossRef]

97. Shashua-Bar, L.; Hoffman, M. Vegetation as a climatic component in the design of an urban street. Energy Build. 2000, 31, 221-235. [CrossRef]

98. Bowler, D.E.; Buyung-Ali, L.; Knight, T.M.; Pullin, A.S. Urban greening to cool towns and cities: A systematic review of the empirical evidence. Landsc. Urban Plan. 2010, 97, 147-155. [CrossRef]

99. Anjos, M.; Lopes, A. Urban Heat Island and Park Cool Island Intensities in the Coastal City of Aracaju, North-Eastern Brazil. Sustainability 2017, 9, 1379. [CrossRef]

100. Gartland, L.M. Heat Islands: Understanding and Mitigation in Urban Areas; Earthscan: London, UK, 2012; 192p.

101. Clay, R.; Guan, H. The urban-parkland nocturnal temperature interface. Urban Clim. 2020, 31, 100585. [CrossRef]

102. Wang, R.; Murayama, Y. Geo-simulation of land use/cover scenarios and impacts on land surface temperature in Sapporo, Japan. Sustain. Cities Soc. 2020, 63, 102432. [CrossRef]

103. Mehrotra, S.; Bardhan, R.; Ramamritham, K. Diurnal thermal diversity in heterogeneous built area: Mumbai, India. Urban Clim. 2020, 32, 100627. [CrossRef]

104. Chen, Y.C.; Liao, Y.-J.; Yao, C.-K.; Honjo, T.; Wang, C.-K.; Lin, T.-P. The application of a high-density street-level air temperature observation network (HiSAN): The relationship between air temperature, urban development, and geographic features. Sci. Total Environ. 2019, 685, 710-722. [CrossRef] [PubMed]

105. Sun, R.; Chen, L. How can urban water bodies be designed for climate adaptation? Landsc. Urban Plan. 2012, 105, 27-33. [CrossRef]

106. Firozjaei, M.K.; Weng, Q.; Zhao, C.; Kiavarz, M.; Lu, L.; Alavipanah, S.K. Surface anthropogenic heat islands in six megacities: An assessment based on a triple-source surface energy balance model. Remote Sens. Environ. 2020, 242, 111751. [CrossRef] 